\title{
ABOUT THIS BOOK
}

\section{Definition of Western North America}

We define "the West" to include the states and Canadian provinces and parts thereof west of a line drawn along the eastern base of the western cordillera, from the British and Richardson mountains, Yukon Territory; and Mackenzie Mountains, Northwest Territory; along the Rocky Mountains from northeastern British Columbia, western Alberta, Montana, Wyoming, and Colorado; to New Mexico along the Sacramento Mountains; and western Texas along the Guadalupe, Davis, and Chisos mountains (Fig. 1). We mention transcontinental and other extralimital ranges, but we do not treat species that are restricted to regions east of the defined part of western North America.

\section{Selection of Species}

For each family, subfamily, and larger genus we aimed to discuss and illustrate about $25 \%$ of the named moth species known to occur in the West. Criteria that we used to select the species included, not necessarily in order of priority, are that they be (1) widespread, well-known species, especially those of economic importance in agriculture, forestry, garden and turf management, and stored products; (2) species for which we have information on life cycle and biology, particularly the larval foods; (3) distinctive or showy species and those otherwise liable to be easily recognized, especially in populated areas; (4) species with special adaptations, behavioral or morphological, even if they are obscure or local in occurrence; (5) a generic representation: ideally all genera might have been treated, but including at least one species from every genus would have exceeded $25 \%$ of the total in some taxa, and many of those would be poorly known species. Therefore, we excluded many monotypic genera or those with only one or a few species in the West for which scant information is available. Some families with only one or a few species are proportionately better represented (e.g., essentially all Micropterigidae, Acanthopteroctetidae, Incurvariidae, Adelidae, Schreckensteiniidae, Zygaenoidea, and Doidae). In summary, we selected the better-known species for which we have biological or other interesting information.

\section{Scientific and Common Names}

Animal names are governed by the International Code of Zoological Nomenclature (ICZN), which is among the very few laws agreed upon by all nations. The primary value of our scientific name system, and the reason it has been used in the same format for 250 years, is its universality. The genus name must be unique, different from every other animal's generic name, and the names are used in the same Latinized form worldwide. As our knowledge and the number of described species increase, species names change, especially because they are moved from one genus to another, or a species is found to be the same as an earlier described one, whose name takes priority.

Animals are classified by a hierarchy of categories called taxa (singular: taxon), with each higher taxon containing one to many of the next subordinate category. Within the animal kingdom, there are six obligate ranks that define the position of every species: phylum, class, order, family, genus, and species. The scientific name of every animal is based on the two lowest-rank categories, genus (plural: genera) and species (plural: species). Hence the name has two parts, the generic name, the first letter of which is always capitalized, followed by the specific name, the first letter of which is not capitalized. Animal names usually are given in italics. Thus an animal's name is more than a name because it is informative on relationships; the species is more closely related to other members of its genus than it is to those of other genera. Similarly, knowing the name of the family to which a species belongs tells us much about its relationships; genera in the same family are closer relatives than any of them is to genera in other families.

As an example, the largest moth in western North America, Ascalapha odorata (Linnaeus), is classified as

Phylum Arthropoda, which includes all animals with a hard exoskeleton and jointed appendages

Class Insecta, arthropods with three body sections and six pairs of legs

Order Lepidoptera, the moths and butterflies; having a covering of scales and sucking proboscis formed from the maxillary laciniae 


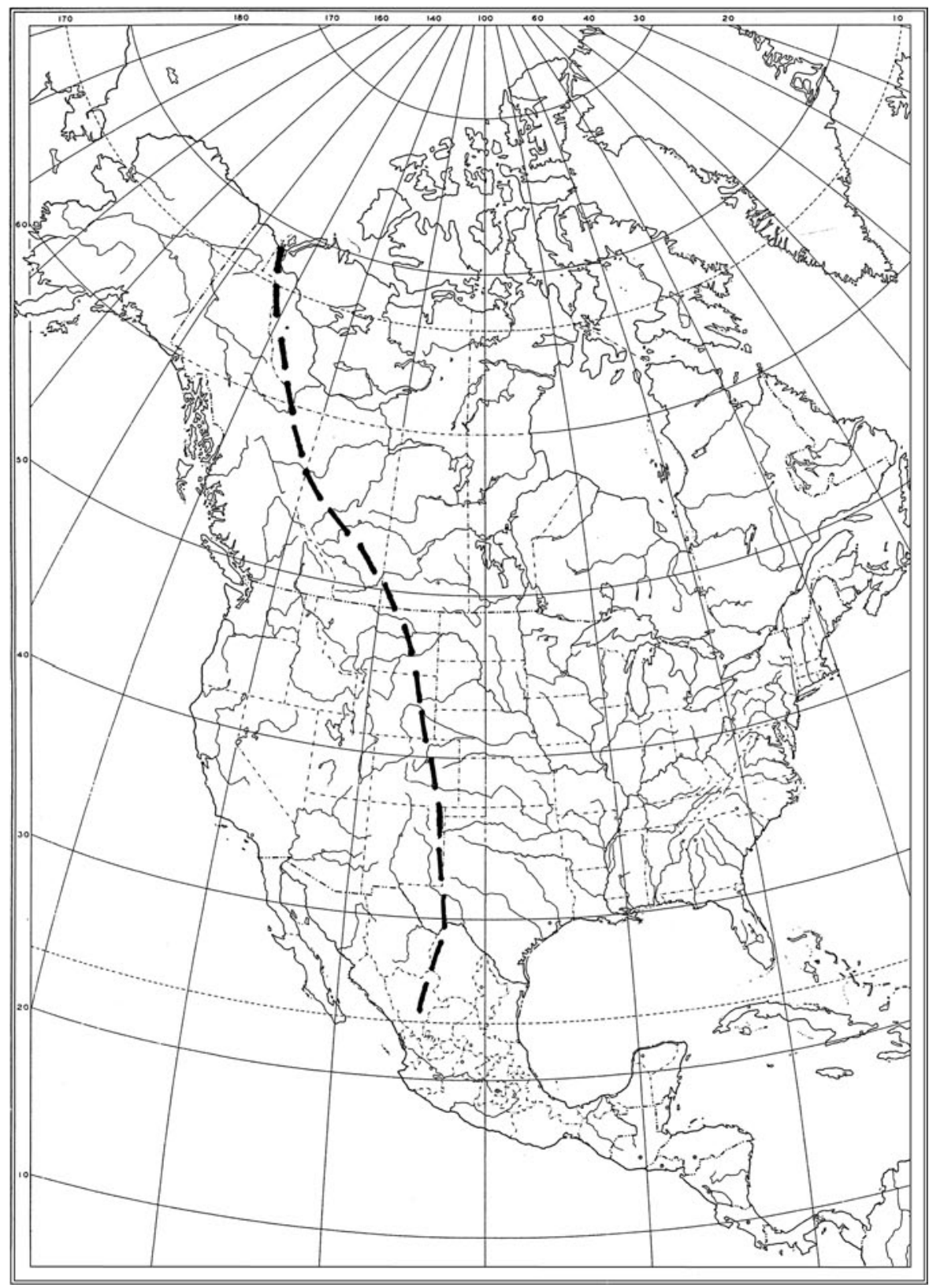

FIGURE 1. Map of North America with the western portion defined for faunal representation in ths book delineated by the bold, broken line.

Family Noctuidae, moths with thoracic tympana

Genus Ascalapha

Species odorata, a name proposed by Linnaeus in 1758, in the tenth edition of his Systema Naturae, which was later selected as the starting base of our binomial nomenclature system.

The author who originally proposed a species name usually is listed with the genus and species, to complete the name; the author's name is placed in parentheses if the species has been assigned to a genus different from its original combination.

In addition, several intermediate ranks are commonly employed for insects because there are vast numbers of species. In Lepidoptera, more than 120 families are defined, which are grouped into about 44 superfamilies. Many families are divided into subfamilies, and larger subfamilies into tribes, each of which contains one to many genera. Typically these intermediate ranks are used primarily by specialists, enabling communication about additional levels of relationships. For example, there are 9,000 described species of the family Tortricidae worldwide, and these are assigned to three subfamilies, which have 11 , three, and eight tribes in which their genera are classified. Without the intermediate categories, comprehension of relationships among the more than a thousand genera would be exceedingly difficult, even for the most dedicated specialist. Moreover, endings for the names of ranks between genus and order are spelled out in the ICZN. Thus, -oidea for superfamily, -idae for family, -inae for subfamily, and -ini for tribe are consistently used and provide immediate recognition of the relative position of the group within its lineage.

Common or vernacular names for species vary from place to place for the same animal, particularly but not limited to species that occur in countries using different languages, and there are no rules governing their proposal or priority. Thus 
Ascalapha odorata, mentioned above, is called the "black witch" in the United States but has a different common name, and probably more than one, in Mexico and other Spanish-speaking countries. A species often has more than one common name, depending upon where it is applied or in what circumstance. For example the noctuid moth Heliocoverpa zea is called the "corn earworm", "tomato fruitworm," and "cotton bollworm" in different places, depending on which crop it is infesting. In this book, we used the common names approved by the Entomological Society of America and those established in various books for some other species, which, however, sometimes contradict one another. We did not propose new common names for any of the vast majority of moth species that lack them.

\section{Literature}

We refer to authors of major works, such as the chapters in Kristensen's 1999 volume in Handbook of Zoology, or a systematic revision of a particular group, as in the Moths of America North of Mexico, but do not cite references in the text. General references that treat many families (e.g., Prentice and others in Forest Lepidoptera of Canada) appear in a bibliography at the end of this introduction. Taxonomically restricted publications on individual families or larger genera are cited at the end of each chapter. These contain the sources of much of our text and will provide an entry into the literature for most taxa. Of course, we have referred to hundreds of other publications in scientific journals that treat individual species or specific topics, citation of which is beyond the practical scope of this book.

\section{Figures and Color Plates}

Most of the line drawing figures depict moth genitalia, detailed comparison of which often is essential for identifying genera and species. We provide exemplar illustrations representing both sexes of one to several genera for most families. In some cases, these depict species for which there are no accounts in our text because better illustrations were available, from which our drawings were made, than was true for discussed species.

See color section for an explanation of how to use the plates.

\section{Measurements}

Size of adults is estimated by fore-wing length, measured from base to apex including the fringe. Using a micrometer disk, we measured five or more of the largest and smallest specimens available to obtain a range of fore-wing lengths, to $0.1 \mathrm{~mm}$ accuracy for tiny moths, and to $0.5 \mathrm{~mm}$ accuracy for intermedi- ate-sized moths (ca. 6 to $20 \mathrm{~mm}$ ). Measurements in centimeters accurate to $0.2 \mathrm{~cm}$ were made for larger moths, using vernier calipers.

\section{Abbreviations}

Generic names of both plants and insects often are abbreviated by their first letter if already spelled out in the same paragraph. Body parts with abbreviations are illustrated in Figs. 2, 3, and 18 to 24 . Abdominal segments are numbered 1 to 10 (or A1 to A10), basal to caudal. In addition to morphological terms cited in the figures, the following abbreviations are used:

\begin{tabular}{|c|c|}
\hline FW & fore wing(s) \\
\hline HW & hind wing(s) \\
\hline Sc, $\mathrm{R}, \mathrm{M}, \mathrm{Cu}, \mathrm{A}$ & $\begin{array}{l}\text { wing vein systems: subcostal, radial, } \\
\text { medial, cubital, anal (Figs. } 4-17 \text { ) }\end{array}$ \\
\hline $\mathrm{cm}$ & centimeter $(1$ inch $=2.54 \mathrm{~cm})$ \\
\hline $\mathrm{mm}$ & millimeter $(10 \mathrm{~mm}=1 \mathrm{~cm})$ \\
\hline $\mathrm{m}$ & meter $(100 \mathrm{~cm}=1 \mathrm{~m}=3.28$ feet $)$ \\
\hline $\mathrm{km}$ & kilometer $(1,000 \mathrm{~m}=1 \mathrm{~km}=0.61$ miles $)$ \\
\hline $\mathrm{mi}$ & mile \\
\hline Co. & County \\
\hline MONA & Moths of America North of Mexico \\
\hline Mt., Mtn., Mtns. & mount, mountain, mountains \\
\hline MyBP & million years before the present \\
\hline & feet (elevation) \\
\hline
\end{tabular}

Institutional collection acronyms:

\begin{tabular}{|c|c|}
\hline AMNH & $\begin{array}{l}\text { American Museum of Natural History, } \\
\text { New York }\end{array}$ \\
\hline $\mathrm{CNC}$ & Canadian National Collection, Ottawa \\
\hline CSAC & $\begin{array}{l}\text { California State Arthropod Collection, } \\
\text { Department of Food and Agriculture, } \\
\text { Sacramento }\end{array}$ \\
\hline CSUC & $\begin{array}{l}\text { C. P. Gillette Museum of Arthropod Diversity, } \\
\text { Colorado State University, Ft. Collins }\end{array}$ \\
\hline EME & $\begin{array}{l}\text { Essig Museum of Entomology, University of } \\
\text { California, Berkeley }\end{array}$ \\
\hline LACM & $\begin{array}{l}\text { Los Angeles County Museum of Natural } \\
\text { History, Los Angeles }\end{array}$ \\
\hline PMY & $\begin{array}{l}\text { Peabody Museum, Yale University, New } \\
\text { Haven, Conn. }\end{array}$ \\
\hline SBNHM & $\begin{array}{l}\text { Santa Barbara Natural History Museum, Santa } \\
\text { Barbara, Calif. }\end{array}$ \\
\hline SDMNH & $\begin{array}{l}\text { San Diego Museum of Natural History, } \\
\text { San Diego }\end{array}$ \\
\hline UCD & $\begin{array}{l}\text { Bohart Museum of Entomology, University of } \\
\text { California, Davis }\end{array}$ \\
\hline USNM & $\begin{array}{l}\text { U.S. National Museum of Natural History, } \\
\text { Washington, D.C. }\end{array}$ \\
\hline
\end{tabular}


This page intentionally left blank 